\title{
GAMBARAN POLA ASUH DAN POLA MAKAN ANAK USIA 2-5 TAHUN DI KELURAHAN TAIPA KECAMATAN PALU UTARA
}

\section{DESCRIPTION OF PARENTAL AND CHILDREN'S FOOD PATTERNS AT AGE 2-5 YEARS IN TAIPA SUB-DISTRICT, NORTH PALU DISTRICT}

\author{
Elvyrah Faisal, Dwi Erma Kusumawati, Aan Happy Desriani \\ Poltekkes Kemenkes Palu \\ (virafaisal@yahoo.com, 08114049394)
}

\begin{abstract}
ABSTRAK
Anak usia 2-5 tahun merupakan salah satu kelompok rawan gizi, pada masa ini terjadi penurunan laju pertumbuhan, menurunnya pertumbuhan diikuti oleh menurunnya nafsu makan. Hasil Riskesdas (2013) menunjukan bahwa terdapat masalah status gizi di Sulawesi Tengah, diantaranya adalah prevalensi stunting sebesar $40 \%$, prevalensi balita gizi kurang sebesar $25 \%$, prevalensi balita kurus sebesar 15\% dan BBLR (Berat Badan lahir Rendah) sebesar 18\%. Sementara prevalensi untuk proporsi anak Stunting di Kota Palu tahun 2013 sebesar 35\%, prevalensi balita kurus 12\%, dan untuk kasus gizi buruk memiliki prevalensi sebesar $17 \%$. Tujuan penelitian adalah untuk mengetahui gambaran pola asuh dan pola makan anak usia 2-5 tahun di Kelurahan Taipa Kecamatan Palu Utara. Jenis penelitian ini adalah deskriptif. Sampel dalam penelitian ini adalah anak usia 2-5 tahun sejumlah 77 balita. Teknik pengambilan sampel dalam penelitian ini menggunakan metode stratified random sampling. Hasil penelitian menunjukan bahwa pola asuh yang diterapkan orang tua kepada anak adalah tidak otoriter, tidak demokrasi dan permisif. Bahan makanan sumber karbohidrat yang sering dikonsumsi adalah beras, sumber protein hewani adalah ikan katombo, telur ayam, sayur yang sering dikonsumsi adalah sayur kelor. Tidak ada buah yang sering dikonsumsi oleh anak. Kesimpulan dari penelitian ini adalah pola asuh yang diterapkan oleh orang tua kepada anak di Kelurahan Taipa Kecamatan Palu Utara yang paling dominan adalah pola asuh demokrasi dimana terdapat 71 orang tua yang menerapkan pala asuh jenis ini dan bahan makanan yang sering dikonsumsi adalah beras, ikan katombo, telur ayam dan sayur kelor.

Kata Kunci: Pola Asuh, Pola Makan
\end{abstract}

\section{ABSTRACT}

Children aged 2-5 years are one of the nutrition-prone groups, during this period a decline in growth rate, decreased growth followed by decreased appetite. Based on Riskesdas (2013), there were nutritional status problems in Central Sulawesi, including the prevalence of Stunting by $40 \%$, prevalence of underfive malnutrition by $25 \%$, prevalence of underweight toddlers by $15 \%$ and LBW (Low birth weight) by 18\%. While the prevalence for the proportion of Stunting children in Palu according to Riskesdas Central Sulawesi in 2013 was 35\%, the prevalence of underweight children was $12 \%$, and for cases of malnutrition had a prevalence of $17 \%$. The purpose of this study was to determine the description of parental and food patterns of children aged 2-5 years in Taipa District, North Palu District. This type of research is descriptive. The sample in this study were children aged 2-5 years totaling 77 toddlers. The sampling technique in this study uses the stratified random sampling method. The results showed that parental applied by parents to children is not authoritarian, not democratic and permissive. food sources of carbohydrates that are often consumed are rice, animal protein sources are catfish, chicken eggs, vegetables that are often consumed are Moringa vegetables. There is no fruit that is often consumed by children. The conclusion of this study is the parental applied by parents to children in Taipa Village, North Palu District, the most dominant is democratic parenting, where there are 71 parents who apply this type of fostering and food that is often consumed is rice, catfish, chicken egg and moringa vegetable.

Keyword: Parenting, Food Patterns 


\section{PENDAHULUAN}

Masa depan suatu bangsa dan negara dimasa yang akan datang ditentukan oleh setiap generasi yang terlahir di negara dan bangsa itu sendiri oleh karena itu anak merupakan harta yang sangat berharga bagi negara dan bangsa, karena ditangan merekalah penentu kemajuan suatu negara dan bangsa ${ }^{(1)}$.

Dalam pertumbuhan anak membutuhkan orang yang dapat mengasuhnya dengan baik contohnya ibu, ibu memiliki peran penting dalam pertumbuhan seorang anak dimana ibu diharapkan dapat mengatur pola makan dan pola asuh anak dengan baik sehingga pertumbuhan anakpun akan baik. Seorang ibu berkewajiaban untuk menjaga anak, bukan hanya saat masih bayi tetapi sampai dewasa dalam masa-masa pertumbuhan anak ibu diharapkan berada disana dalam menjaga dan mengasuhnya agar tumbuh dengan baik ${ }^{(2)}$.

Usia 2-5 tahun merupakan salah satu kelompok usia yang rentan terhadap masalah kesehatan kerena kurang gizi, hal ini sebabkan oleh beberapa hal diantaranya adalah anak pada usia ini berada dalam masa transisi dari makanan bayi kemakanan orang dewasa, biasanya anak balita sudah mempunyai adik, atau ibunya sudah bekerja penuh sehingga perhatian ibu sudah berkurang, anak balita sudah mulai main di tanah, dan sudah dapat main di luar rumahnya sesehingga dapat terpapar dengan lingkungan yang kotor dan kondisi yang memungkinkan untuk terinfeksi dengan berbagai macam penyakit, anak 2-5 tahun belum dapat mengurus dirinya sendiri termasuk dalam memilih makanan. Dipihak lain ibunya sudah tidak begitu memperhatikan lagi makanan anak karena dianggap sudah dapat makan sendiri ${ }^{(3)}$.

Berdasarkan hasil Riskesdas pada tahun 2013 menunjukan bahwa masih terdapat masalah status gizi di Sulawesi Tengah, diantaranya adalah prevalensi Stunting sebesar $40 \%$, prevalensi Balita Gizi kurang sebesar 25\%, prevalensi Balita kurus sebesar 15\% dan BBLR (Berat Badan lahir Rendah) sebesar 18\%. Sementara prevalensi untuk proporsi anak Stunting di Kota Palu menurut Riskesdas Sulawesi Tengah pada tahun 2013 sebesar $35 \%$, prevalensi balita kurus $12 \%$, dan untuk kasus gizi buruk memiliki prevalensi sebesar $17 \%$. Berdasarkan data ini menunjukan bahwa masih terdapat masalah gizi pada anak di kota palu ${ }^{(4)}$.

$$
\text { Menurut penelitian yang }
$$

dilakukan oleh Fatimah tahun 2012 mengenai hubungan pola asuh orang tua dengan perkembangan anak di R.A Darussalam Desa Sumber Mulyo, Jogoroto, Jombang menyebutkan bahwa ada hubungan antara pola asuh orang tua 
dengan perkembangan anak, oleh karena itu diharapkan orang tua bisa memberikan pola asuh yang terbaik untuk anaknya, sehingga perkembangan anak bisa maksimal, mengingat bahwa anak merupakan aset bangsa yang ditangan merekalah penentuan kemajuan bangsa ini (5).

Berdasarkan hasil penelitian yang dilakukan oleh Kurniawati tahun 2017 tentang hubungan pola asuh ibu bekerja terhadap status gizi balita usia 1-5 tahun di wilayah puskesmas Kasihan 1, Bantul, Yogyakarta didapatkan hasil bahwa sebagian besar ibu balita dengan pola asuh yang baik mayoritas status gizi balita adalah normal yaitu sebanyak 30 responden $(55,6 \%)$, begitu pula ibu balita dengan pola asuh yang kurang baik juga mayoritas memiliki balita dengan status gizi normal namun jumlahnya lebih sedikit yaitu sebanyak 14 responden $(25,9 \%)$, dengan demikian dapat ditarik kesimpulan bahwa pengasuhan ibu terhadap anak dapat mempengaruhi pertumbuhan dan perkembangan anak ${ }^{(6)}$.

Taipa adalah bagian dari Kecamatan Palu Utara. Kelurahan Taipa adalah lokasi yang semi perkotaan, dengan status ini diharapkan Taipa Laga tidak lagi memiliki masalah kesehatan dengan melihat bahwa insfrastruktur kesehatan yang sudah cukup baik disekitar daerah setempat akan tetapi, berdasarkah hasil pengumpulan data yang dilakukan oleh Mahasiswa gizi tahun 2017 dalam rangka Pelaksanaan Program Gizi di Kelurahan Taipa wilaya kerja Taipa Laga dan Labuan Beru Kecamatan Palu Utara didapatkan data bahwa masih terdapat masalah gizi pada anak usia 0-60 bulan, dari 63 balita yang di ukur untuk kategori BB/U didapatkan hasil bahwa prevalensi anak gizi buruk sebesar $10 \%$, prevalensi gizi kurang sebesar $11 \%$, prevalensi gizi baik sebesar $42 \%$, dan prevalensi gizi lebih $13 \%$ hal ini secara tidak langsung dapat menggambarkan keadaan kesehatan anak di Kelurahan Taipa.

Berdasarkan uraian diatas peneliti tertarik untuk melihat pola dan pola makan anak usia 2-5 tahun di Kelurahan Taipa kecamatan Palu utara.

\section{METODE PENELITIAN}

Jenis penelitian yang digunakan adalah jenis penelitian deskriptif bertempat di Kelurahan Taipa Kecamatan Palu Utara pada bulan juni - agustus 2018. Populasi penelitian adalah seluruh anak usia 2-5 tahun di Kelurahan Taipa Kecamatan Palu Utara sejumlah 335 balita. Jumlah sampel sebesar 77 balita diperoleh dari hasil perhitungan menggunakan rumus slovin dengan Teknik pengambilan sampel menggunakan metode stratified random sampling. Analisis data yang digunakan adalah analisis univariat dan disajikan dalam bentuk tabel dan narasi. 


\section{HASIL}

\section{Gambaran Pola Asuh}

Pengasuhan anak dapat dibagi menjadi tiga jenis pola asuh diantaranya adalah pola asuh otoriter, demokrasi dan permisif. Berdasarkan tabel 1 menunjukan bahwah jumlah orang tua yang menerapkan sistem pola asuh yang tidak otoriter yakni sebanyak $18(23, \%)$ orang tua dan tidak menerapkan pola asuh otoriter adalah 59 $(76,6 \%)$ orang tua.

Tabel 1 Distribusi frekuensi pola asuh otoriter

\begin{tabular}{lcc}
\hline Jenis Pola Asuh & $\mathbf{f}$ & $\mathbf{\%}$ \\
\hline Tidak Otoriter & 18 & 23,4 \\
Otoriter & 59 & 76,6 \\
\hline Total & $\mathbf{7 7}$ & $\mathbf{1 0 0}$ \\
\hline
\end{tabular}

Sumber: Data primer, 2018

Berdasarkan tabel 2 menunjukan bahwah jumlah orang tua yang menerapkan sistem pola asuh yang tidak demokrasi yakni sebanyak $6 \quad(7,8 \%)$ orang tua yang menerapkan pola asuh demokrasi adalah 71 $(92,2, \%)$ orang tua.

Tabel 2 Distribusi frekuensi pola asuh demokrasi

\begin{tabular}{lcc}
\hline Jenis Pola Asuh & $\mathbf{f}$ & $\mathbf{\%}$ \\
\hline Tidak Demokrasi & 6 & 7,8 \\
Demokrasi & 71 & 92,2 \\
\hline Total & $\mathbf{7 7}$ & $\mathbf{1 0 0}$ \\
\hline
\end{tabular}

Sumber: Data primer, 2018

Berdasarkan tabel 3 menunjukan bahwa jumlah orang tua yang menerapkan sistem pola asuh tidak permisif yakni sebanyak $40(51,9 \%)$ orang tua dan yang menerapkan pola asuh permisif adalah 37 $(48,1 \%)$ orang tua.
Tabel 3 Distribusi frekuensi pola asuh permisif

\begin{tabular}{lcc}
\hline Jenis Pola Asuh & f & \% \\
\hline Tidak Permisif & 40 & 51,9 \\
Permisif & 37 & 48,1 \\
\hline Total & $\mathbf{7 7}$ & $\mathbf{1 0 0}$ \\
\hline
\end{tabular}

Sumber: Data primer, 2018

\section{Gambaran Frekuensi Bahan Makanan}

Masyarakat di Kelurahan Taipa mengkonsumsi beberapa jenis bahan makanan. Berdasarkan tabel 4 menunjukan bahwa frekuensi makanan sumber karbohidrat yang paling sering dikonsumsi $\geq$ $50 \%$ adalah nasi, untuk makan sumber protein hewani adalah ikan katombo dan telur ayam, protein nabati adalah tahu, untuk sayuran adalah kelor sedangkan untuk buahbuahan tidak ada buah yang termasuk dalam kategori sering dikonsumsi.

\section{PEMBAHASAN}

Dalam mengasuh anak terdapat tiga jenis pola asuh diantaranya adalah pola asuh otoriter, demokrasi dan permisif. Pola asuh otoriter adalah pola asuh yang memaksa anak untuk tunduk pada perintah orang tua, pola asuh jenis ini beranggapan bahwa semua kekuasaan berada ditangan orang tua karena orang tua lebih mengetahui apa yang baik bagi anak. Pola asuh demokrasi mengajarkan adanya sikap keterbukaan antara orang tua dan anak, pola asuh demokrasi adalah pola asuh yang memberikan ruang kepada anak untuk menyampaikan apa yang diinginkan anak, 
Tabel 4 Distribusi konsumsi frekuensi bahan makanan pada anak usia 2-5 tahun di Kelurahan Taipa Kecamatan Palu Utara

\begin{tabular}{|c|c|c|c|c|c|}
\hline \multirow[b]{2}{*}{ Jenis Bahan Makanan } & \multirow[b]{2}{*}{ Sering } & \multicolumn{3}{|c|}{ Frekuensi Makan } & \multirow[b]{2}{*}{ Pola Makar } \\
\hline & & $\%$ & Jarang & $\%$ & \\
\hline Beras & 77 & 100 & 0 & 0 & Sering \\
\hline Jagung & 14 & 18,2 & 63 & 81,8 & Jarang \\
\hline Ubi & 13 & 16,9 & 64 & 83,1 & Jarang \\
\hline Sagu & 1 & 1,3 & 76 & 98,7 & Jarang \\
\hline Tepung terigu & 31 & 40,3 & 46 & 59.7 & Jarang \\
\hline Daging Ayam & 6 & 7.8 & 71 & 92.2 & Jarang \\
\hline Daging Kambing & 0 & 0 & 77 & 100 & Jarang \\
\hline Daging Sapi & 3 & 3,9 & 74 & 96.1 & Jarang \\
\hline Ikan Bandeng & 0 & 0 & 77 & 100 & Jarang \\
\hline Ikan Cakalang & 10 & 13,9 & 67 & 86.1 & Jarang \\
\hline Ikan Katombo & 39 & 50,9 & 38 & 49.1 & Sering \\
\hline Ikan Mujair & 3 & 3,9 & 74 & 96,1 & Jarang \\
\hline Ikan Tongkol & 7 & 9.1 & 70 & 50,9 & Jarang \\
\hline Telur Ayam & 50 & 64.9 & 27 & 35.1 & Sering \\
\hline Telur Bebek & 0 & 0 & 77 & 100 & Jarang \\
\hline Cumi-cumi & 2 & 2,6 & 75 & 97,4 & Jarang \\
\hline Udang & 1 & 1,3 & 76 & 98,7 & Jarang \\
\hline Kacang Tanah & 1 & 1,3 & 76 & 98,7 & Jarang \\
\hline Tahu & 51 & 66.2 & 26 & 33.8 & Sering \\
\hline Tempe & 38 & 49.4 & 39 & 50.6 & Jarang \\
\hline Kacang Hijau & 0 & 0 & 77 & 100 & Jarang \\
\hline Bayam & 15 & 19.5 & 62 & 80,5 & Jarang \\
\hline Kacang Panjang & 12 & 15,6 & 65 & 84,4 & Jarang \\
\hline Kangkung & 28 & 36.4 & 49 & 63.6 & Jarang \\
\hline Ketimun & 7 & 9,1 & 70 & 90.9 & Jarang \\
\hline Kembang Kool & 2 & 2,6 & 75 & 97.4 & Jarang \\
\hline Kool & 6 & 7,8 & 71 & 92,2 & Jarang \\
\hline Kelor & 55 & 71,5 & 22 & 26.5 & Sering \\
\hline Labu siam & 7 & 9.1 & 70 & 90,9 & Jarang \\
\hline Sawi & 6 & 7,8 & 71 & 92.2 & Jarang \\
\hline Tauge & 6 & 7,8 & 71 & 92,2 & Jarang \\
\hline Tomat & 57 & 74 & 20 & 26,0 & Sering \\
\hline Wortel & 15 & 19,5 & 62 & 80,5 & Jarang \\
\hline Alpukat & 2 & 2,6 & 75 & 97,4 & Jarang \\
\hline Apel & 2 & 2,6 & 75 & 97,4 & Jarang \\
\hline Jeruk Manis & 4 & 5,2 & 73 & 94,8 & Jarang \\
\hline Kedondong & 1 & 1,3 & 76 & 98,7 & Jarang \\
\hline Mangga & 18 & 23,4 & 59 & 76,6 & Jarang \\
\hline Pepaya & 20 & 26 & 57 & 74,0 & Jarang \\
\hline Pisang & 28 & 36,4 & 49 & 63,6 & Jarang \\
\hline Semangka & 14 & 18,2 & 63 & 81,8 & Jarang \\
\hline Sirsak & 2 & 2,6 & 75 & 97,4 & Jarang \\
\hline Salak & 5 & 6,5 & 72 & 93,5 & Jarang \\
\hline Buah Naga & 2 & 2,6 & 75 & 97,4 & Jarang \\
\hline
\end{tabular}

Sumber: Data primer, 2018 
dengan batasan-batasan tertentu. Pola asuh permisif adalah pola asuh yang selalu memberikan kebebasan kepada anak untuk melakukan apa yang menjadi kemauan anak.

Berdasarkan hasil penelitian ini, didapatkan hasil bahwa pola asuh orang tua terhadap anak di Kelurahan Taipa Kecamatan Palu Utara yang paling dominan adalah pola asuh demokrasi dimana didapatkan hasil bahwa terdapat 71 orang tua menerapkan pola asuh demokrasi terhadap anak. Menurut asumsi peneliti tentang pola asuh demokrasi yang dominan diterapkan oleh orang tua terhadap anak di Kelurahan Taipa Kecamatan Palu Utara karena orang tua telah mengetahui pola asuh yang baik bagi anak didukung dengan pendidikan yang dimiliki serta telah banyak mendapat edukasi dari berbagai pihak dan juga Kelurahan Taipa Kecamatan Palu Utara adalah wilayah semi perkotaan yang telah banyak mengikuti perkembangan zaman.

Pola asuh dengan jenis Otoriter dan permisif terdapat pada $59(76, \%)$ orang tua menerapkan pola asuh jenis otoriter sedangkan untuk pola asuh jenis permisif terdapat $37(48,1 \%)$ orang tua menerapkan pola asuh jenis permisif, hasil ini menunjukan bahwa ternyata dalam satu keluarga menerapkan dua jenis pola asuh kepada anak baik permisif dengan demokrasi maupun demokrasi dan permisif ataupun karena keterbatasan pertanyaan dikuisioner pada saat melakukan wawancara.

Hasil penelitian ini sejalan dengan penelitian yang dilakukan oleh Kurniawati tahun 2017 tentang hubungan pola asuh ibu bekerja terhadap status gizi balita usia 1-5 tahun di wilayah puskesmas Kasihan 1, Bantul, Yogyakarta didapatkan hasil bahwa pola asuh yang dominan diterapkan ibu adalah pola asuh demokrasi, Pola asuh demokratis mengandung unsur kedinamisan, yang disesuaikan dengan kebutuhan anak, serta menerapkan komunikasi yang efektif sehingga dapat meningkatkan pertumbuhan yang baik. Penerapan pola asuh yang demokratis dapat mendorong anak untuk mandiri, tetapi orang tua tetap dapat memberi batasan dan kontrol (6).

Pola makan merupakan gambaran kebiasaan makan anak yang diambil selama satu bulan terakhir. Dalam hal pola makan anak di Kelurahan Taipa anak paling sering mengkonsumsi bahan makanan sumber karbohidrat adalah beras, sumber protein hewani ikan katombo dan telur ayam, sumber protein nabati tahu dan sayuran adalah daun kelor sedangkan untuk buah-buahan tidak terdapat buah yang sering dikonsumsi Diperolehnya hasil seperti diatas karena memang sumber makan pokok untuk Kelurahan Taipa adalah beras yang kemudian diolah menjadi nasi atau bubur. Sedangkan untuk ubi dan sagu hanya untuk sesekali apabila diinginkan, untuk konsumsi sagu anak mengonsumsinya dari makan olahan seperti dange yang dibuat oleh orang tua dan untuk konsumsi tepung didapatkan dari hasil anakanak mengonsumsi jajan yang berbasar tepung (kue). Untuk anak yang mengonsumsi nasi hanya mencapai 1 kali sehari menurut pengakuan ibu mereka lebih suka mengonsumsi snack atau kue.

Untuk konsumsi makanan sumber 
protein hewani pada anak usia 2-5 tahun di Kelurahan Taipa Kecamatan Palu Utara anakanak banyak mengonsumsi katombo dan telur. ikan katombo dan telur ayam dikonsumsi yakni sebanyak 3-6 kali perminggu, sedangkan untuk bahan makan sumber protein lainnya hanya sesekali dikonsumsi atau jarang dikonsumsi. Hal ini terjadi karena ikan katombo dan telur ayam adalah makanan sumber protein yang paling mudah didapatkan didaerah ini sedangkan untuk bahan makan sumber protein lainya hanya ada pada waktuwaktu tertentu selain itu juga adalah ikan katombo dan telur ayam sudah manjadi bagian dalam pola makan masyarakat di tempat ini.

Untuk konsumsi makanan sumber protein nabati pada anak usia 2- 5 tahun di Kelurahan Taipa Kecamatan Palu Utara yang paling sering dikonsumsi adalalah tahu, sedangkan untuk makanan sumber protein lainnya seperti tempe, kacang tanah dan kacang hijau masuk dalam kategori jarang. Hal ini dapat terjadi karena makanan sumber protein nabati seperti tahu mudah didapatkan setiap harinya serta kesetersediannya juga termasuk banyak, orang tua sering mendapatkanya dari pedagang keliling setiap harinya maupun dari pedagang-pedagang kaki lima disekitar lingkungan rumah mereka. Selain itu, tempe juga termasuk protein nabati yang mudah didapatkan tetapi anak di Kelurahan Taipa lebih sering atau suka mengonsumsi tahu, tempe sering diselangselingkan dengan tahu, akan tetapi tahu lebih sering dikonsumsi. Untuk bahan makanan seperti kacang tanah hanya sekitar 2 kali perbulan dan bahkan tidak dikonsumsi sama sekali dalam sebulan terakhir, untuk kacang hijau pun demikian. Anak mengonsumsi kacang hijau didapatkan dari pemberian Makan Pendamping Air Susu Ibu (MP-ASI) yang didapatkan setiap bulannya di Posyandu dan sesekali dibuatkan oleh orang tua.

Untuk konsumsi sayur pada anak usia 2-5 tahun di Kelurahan Taipa Kecematan Palu Utara, sayur yang sering dikonsumsi anak adalah Kelor. Hal ini karena sayur kelor adalah makan khas Suku Kaili ataupun juga masuk dalam sayur wajib yang disediakan setiap kali makan dengan bermacam-macam olahan baik disediakan dalam bentuk sayur santan ataupun sayur bening. Konsumsi sayur pada anak di Kelurahan Taipa cukup baik, anak bukan hanya konsumsi sayur kelor ada beberapa jenis sayur seperti bayam, kacang panjang, kangkung, labu siam, sawi, kool, tomat, touge, juga dikonsumsi anak secara bergantian tiap harinya, tetapi tidak termasuk dalam kategori sering.

Untuk gambaran konsumsi buah pada anak usia 2-5 tahun di Kelurahan Taipa Kecamatan Palu Utara tidak terdapat buah yang sering dikonsumsi oleh anak. Selain itu juga anak di Kelurahan Taipa Kecamatan Palu Utara sering konsumsi snack-snack yang bermacam-macam.

Akibat dari kurangnya konsumsi buah pada anak akan berpotensi kurangnya sejumlah vitamin yang mengakibatkan konstipasi atau bahkan terjadinya obesitas pada anak. Hal ini menunjukkan bahwa konsumsi sayuran dan buah-buahan yang cukup turut berperan dalam pencegahan penyakit tidak menular kronik sejak dini ${ }^{(1)}$. 


\section{KESIMPULAN DAN SARAN}

Berdasarkan hasil penelitian yang dilakukan di Kelurahan Taipa Kecamatan Palu Utara pada anak usia 2-5 tahun dapat ditarik kesimpulan bahwa pola asuh yang paling dominan diterapkan orang tua kepada anak adalah pola asuh demokrasi dan bahan makanan yang sering dikonsumsi adalah beras, ikan katombo, telur ayam dan sayur kelor. Disarankan kepada orang tua dalam mengasuh anak agar lebih memahami bentuk pola asuh yang diterapkan kepada sejak usia dini. Dan kepada kepada tenaga kesehatan setempat untuk memberikan edukasi tentang pentingnya konsumsi buah dengan frekuensi paling sedikit 3- 6 kali perminggu

\section{UCAPAN TERIMA KASIH}

Terima kasih dapat diberikan kepada 1) Bapak Direktur Poltekkes Kemenkes Palu 2) Lurah Taipa, 3) Camat Taipa, 4) Dinas Kesehatan Provinsi Sulawesi Tengah

\section{DAFTAR PUSTAKA}

1. Kementerian Kesehatan RI. Kondisi Pencapaian Program Kesahatan Anak Indonesia. 2014.

2. Yuniarti S. Asuhan Tumbuh Kembang Neonatus Bayi-Balita dan Anak Prasekolah. Bandung: PT Refika Aditama; 2015.

3. Irianto K. Ilmu Kesehatan Masyarakat. Bandung: Alfabeta; 2014.

4. Badan Penelitian dan Pengembangan Kesehatan. Riset Kesehatan Dasar
(RISKESDAS) 2013. Lap Nas 2013. 2013;1-384.

5. Fatimah L. Hubungan Pola Asuh Orang Tua dengan Perkembangan Anak di R.A Darussalam Desa Sumber Mulyo, Jogoroto, Jombang. Pros Semin. 2012;1(2):6.

6. Kurniawati E. Hubungan Pola Asuh Ibu Bekerja terhadap Status Gizi Balita Usia 1-5 tahun Wilayah Puskesmas Kasihan 1, Bantul, Yogyakarta tahun 2017. 2017; 